\title{
Effect of Sugarcane Smut (Ustilago scitaminea Syd.) on Ultrastructure and Biochemical Indices of Sugarcane
}

\author{
Xiupeng Song ${ }^{1}$, Fenglian $\mathrm{Mo}^{3}$, Krishan K Verma ${ }^{1,2}$, Jinju Wei ${ }^{1}$, Xiaoqiu Zhang ${ }^{1}$, Litao Yang ${ }^{1,2 \#}$ and Yang \\ Rui Li ${ }^{1-3 *}$
}

${ }^{1}$ Sugarcane Research Institute, Guangxi Academy of Agricultural Sciences/Sugarcane Research Center of Chinese Academy of Agricultural Sciences / Key Laboratory of Sugarcane Biotechnology and Genetic Improvement (Guangxi), Nanning, Guangxi 530 007, China

${ }^{2}$ Guangxi Key Laboratory of Crop Genetic Improvement and Biotechnology, Nanning, Guangxi - 530 007, China

${ }^{3}$ College of Agriculture / State Key Laboratory for Conservation and Utilization of Subtropical Agro-Bioresources, Guangxi University, Nanning, Guangxi - 530 004, China

*Corresponding author: Yang-Rui Li, Sugarcane Research Institute, Guangxi Academy of Agricultural Sciences/ Sugarcane Research Center of Chinese Academy of Agricultural Sciences / Key Laboratory of Sugarcane Biotechnology and Genetic Improvement (Guangxi), Nanning, Guangxi - 530 007, China, E-mail: liyr@gxaas.net

"Litao Yang, College of Agriculture / State Key Laboratory for Conservation and Utilization of Subtropical Agro-Bioresources, Guangxi University, Nanning, Guangxi - 530 004, China, E-mail: liyr@gxu.edu.cn

\section{ARTICLE INFO}

Received: 㓞 April 04, 2019

Published: 幽 April 17, 2019

Citation: Xiupeng S, Fenglian M, Krishan K V, Jinju W, Xiaoqiu Z, Litao Y, Yang R L. Effect of Sugarcane Smut (Ustilago scitaminea Syd.) on Ultrastructure and Biochemical Indices of Sugarcane. Biomed J Sci \& Tech Res 17(1)-2019. BJSTR. MS.ID.002950.

Keywords: Biochemical; Sugarcane; Smut; Ustilago scitaminea Syd.; Ultrastructure

\begin{abstract}
Sugarcane smut disease, caused by Ustilago scitaminea Syd., significantly decreases yield in sugarcane production. Guangxi is the dominant sugarcane growing province in China, the leading sugarcane variety ROC22 suffers serious smut disease and results in considerable loss in the sugar industry. In this study, at the part of morphological structure, seedcane setts of sugarcane variety ROC22 was inoculated by dipping and grown in pots with soil, until it appeared smut whips, and then observed the appearance of sugarcane plants and the ultra-structure of bud cells in sugarcane. Settlings were inoculated by syringe and assessed ultra-structure and enzyme activities were assessed. The result indicated that infected sugarcane plant grew a long whip, and the cane stem was very tiny without economic value. The damage of smut infection on bud tissue is serious, the bud cells were out of shape, and the cell contents disappeared. The cell nucleus and nucleolocentrosome were deformated and disintegrated, the chromatin was not well-distributed on the cell nucleus and the nucleolocentrosome generated papillas. Most mitochondria were serious injured and disintegrated, and some of their ridges disappeared and became empty. Leaf samples were taken for the analyses of POD, SOD, PPO, chitinase and $\beta$-1,3-glucanase activity. The result showed that the activities of POD $(+4.08 \%)$, SOD $(+11.83 \%)$, PPO $(+38.46 \%)$ and chitinase $(+12.28 \%)$ were increased except $\beta-1,3$-glucanase $(3.31 \%)$ in different degrees after the smut inoculation. The results suggest that after artificial needle inoculation, the increase percentage was found in different inoculation period.
\end{abstract}

\section{Introduction}

Sugarcane smut, caused by Ustilago scitaminea Syd., is one of the most severe fungal diseases affecting sugarcane productivity, and all producing countries have developed protocols for the protection and control of this disease [1,2], also a significant decrease in sucrose content. Its sucrose accounts for ca. $80 \%$ of the total sugar production globally, and about $90 \%$ of the total sugar production in China. China reported that the disease occurred in Guangzhou in 1932. Diseases are becoming more serious in sugarcane main producing areas, i.e. Guangxi, Guangdong and Yunnan [3]. Smut disease caused loss of sugarcane yield in upcoming years, especially in dryland and perennial sugarcane [4-6], also known as "the death of sugar cane" [3]. One of the most obvious features of this disease is that the diseased cane has a curled black whip that varies from a few to tens of centimeters [7]. The disease can be transmitted in a variety of ways, especially its teliospores can spread over a wide range and long distances with the wind [8].

In addition, the transportation of contaminated sugarcane has become the main method of long-distance transmission [3]. Many studies have shown that the younger inoculation of the upper part of the cane bud is more susceptible than the inoculation of the base bud, that is the young shoot is more susceptible than the old shoot [9]. The invention of electron microscopy has further developed 
cytological studies that allow plants to interact with pathogens. The cellular changes caused by the interaction of different host plants with different pathogens are also different. [10] studied the interaction between rice and rice blast fungus, and found that the arrangement of microtubules and microfilaments in the sheath of rice was very intense after infestation by rice blast. The cell wall is intact, but the cytoplasm is highly aggregated or the organelles are disintegrated [11]. Wenying et al. [12] found that under the stress of sweet potato scab, the ultrastructure of leaf cells of different disease-resistant sweet potato varieties changed significantly, the cell membrane was destroyed, and the chloroplast and mitochondria were also damaged to varying degrees.

The predecessors studied the relationship between various physiological and biochemical metabolic reactions of host cells and plant disease resistance after infecting plants with pathogens. The SOD and POD activity can resist the damage of active oxygen and oxygen free radicals on the cell membrane system, while PAL and PPO can promote the production of a variety of secondary metabolites in plants, thereby preventing the invasion and reproduction of pathogenic bacteria [13-16]. Liping et al. [17] suggested that peroxidase had a certain correlation with sugarcane resistance to smut. The more susceptible varieties were infected with smut, the enzymatic activity increased relatively. The enzymes that act as cell wall hydrolase in defense responses against pathogen infection are $\beta$-1,3-glucanase and chitinase [18]. Plant endogenous hormones are regulators of plant life activities, which are related to the main physiological and biochemical reactions during plant growth, which in turn affect plant growth [19]. Sugarcane disease is the main biological stress of sugarcane production.

After smut infection, the cells in the body will undergo a series of adaptive changes in morphological, physiological and biochemical to protect against pathogen infection. The morphological structure of plants is always compatible with the environment. Adversity affects plant growth and can cause corresponding changes in plant morphological structure. The ultrastructure of host cells will change significantly due to the infection of pathogenic bacteria [20]. During the invasion from the pathogenic fungus to the manifestation of the disease, the plant has undergone a series of morphological changes, including external morphology and internal structure. The external feature of sugarcane plants is a visual representation of the appearance of sugar cane. The physiological metabolism process of plants is related to the structure of cells, and the interdependence between them is very close.

\section{Materials and methods}

\section{Plant Material and Inoculation}

The selected plant material was sugarcane variety ROC22. The pathogen for inoculation was collected from the sugarcane base field of Guangxi University Agricultural College, Nanning, Guangxi, China. After drying, it was sealed with a plastic bag and stored in a $-80^{\circ} \mathrm{C}$. The smut pathogen was inoculated by artificial dipping method, and the spore germination rate of the smut disease was over $91 \%$. A suspension of smut germs at a concentration of $5 \times 106$ spores/ml was prepared with $25 \mathrm{~g}$ of spores and $10 \mathrm{~kg}$ of water [21]. 100 healthy single buds were taken for the test materials. After the warm soup was disinfected, the average was divided into 2 parts, one of which was immersed in the prepared spore suspension, taken out after $30 \mathrm{~min}$, moisturized with a plastic bag and placed at ca. $25^{\circ} \mathrm{C}$. The barrel was planted $24 \mathrm{hr}$ after the temperature in the greenhouse. The blank control replaces the bacterial spore suspension with sterile water, and the rest of the operation is the same.

\section{Preparation and Observation of Ultrastructure}

Cut the healthy and susceptible sugarcane buds with a doublesided blade. The strips cut to a size of $1 \times 2 \mathrm{~cm}$ were placed in a $2 \mathrm{~cm}$ diameter vial for aspiration treatment. After evacuation, the material was removed and surrounded by a fixative. Edge excision, finally cut the material into $1 \times 2 \mathrm{~mm}$ tissue pieces, immediately put the material into $4 \%$ paraformaldehyde and $2.5 \%$ glutaraldehyde (0.1 mol / L phosphate buffer, pH 7.2) $4^{\circ} \mathrm{C}$ After fixing for $24 \mathrm{~h}, 0.1 \mathrm{~mol} / \mathrm{L}$ phosphate buffer (pH 7.2), 1\% citric acid (0.1 mol/L phosphate buffer, pH 7.2) was fixed at $4{ }^{\circ} \mathrm{C}$ overnight, and $0.1 \mathrm{~mol} / \mathrm{L}$ (pH 7.2). After washing with phosphate buffer, it was dehydrated with a series of alcohol gradients, then transferred with acetone. Spurt resin was infiltrated and embedde and sliced on an ultrathin slicer. After staining with uranyl acetate and lead citrate, respectively. To observations were made by transmission electron microscope (TEM).

\section{Enzyme extraction}

The sample +1 leaf and cut off the two ends about $3 \mathrm{~cm}$, remove the midrib, weigh $1 \mathrm{~g}$ of the sample, quickly cut it, put it into the mortar precooled with liquid nitrogen, add a little quartz sand and $0.1 \mathrm{~g}$ PVP, add liquid nitrogen grinding crush, add $2 \mathrm{~mL}$ of extract and quickly grind into homogenate. Transfer the homogenate into a $15 \mathrm{ml}$ centrifuge tube, then take $2 \mathrm{~mL}$ of the extract and collect the homogenate on the mortar and pestle. At $4^{\circ} \mathrm{C}$, the tube was shaken for $5 \mathrm{~min}$, placed in an ice box, centrifuged at $12000 \mathrm{r} / \mathrm{min}$ for 4 $\min \left(4^{\circ} \mathrm{C}\right)$, and the supernatant was taken. The supernatant used for biochemical enzyme assays.

\section{Determination of POD, SOD, PPO, Chitinase and $\beta-1,3$ - glucanase indices}

According to Baoju and Fengyun, 1998, slightly modified. Take $0.1 \mathrm{~mol} / \mathrm{L}$ (pH 5.8) phosphate buffer (containing $18 \mathrm{mmol} / \mathrm{L}$ guaiacol) $4.8 \mathrm{~mL}$ into a $10 \mathrm{~mL}$ tube and mix well with $50 \mu \mathrm{L}$ of the crude enzyme extract. Then, it was placed in a $35^{\circ} \mathrm{C}$ water bath for $1 \mathrm{~min}$, and measured wavelength of $470 \mathrm{~nm}$. Slightly modified to the method of Chen et al. [22]. The enzyme reaction, i.e. $4 \mathrm{~mL}$ of mixed reaction solution containing $1.3 \mu \mathrm{mol} / \mathrm{L}$ riboflavin, $13 \mathrm{mmol} / \mathrm{L}$ methionine, $63 \mu \mathrm{mol} / \mathrm{L} \mathrm{NBT}, 0.05 \mathrm{~mol} / \mathrm{L}$ phosphate buffer ( $\mathrm{pH} 7.8$ ). The enzyme activity was measured $570 \mathrm{~nm}$ wavelength, expressed by inhibiting $50 \%$ of the NBT photochemical reaction as an enzyme activity. Take $0.1 \mathrm{~mol} / \mathrm{L} \mathrm{pH} 6.8$ phosphate buffer (containing $0.02 \mathrm{~mol} / \mathrm{L}$ catechol) $4.9 \mathrm{~mL}$ into a $10 \mathrm{~mL}$ tube, and add $100 \mu \mathrm{L}$ of the crude enzyme extract. After reacting for $5 \mathrm{~min}$ in a constant temperature water bath at $35^{\circ} \mathrm{C}$, the absorbance was measured at $398 \mathrm{~nm}$ by colorimetry method. The extraction of chitinase solution was carried out according to the method of Boller et al. [23]. The chitinase activity was determined by Tang [24]. The activity of 
$\beta$-1,3-glucanase was determined by the method of Yongting et al. [25].

\section{Data Processing}

The test data were analyzed using Microsoft Excel and SPSS 15.0 software, and the significance test was performed using Duncan's new complex range method.

\section{Results and Discussion}

\section{Development of Morphology and Ultrastructure of} Sugarcane during Smut Infection

When sugar cane is infected to a certain extent by smut, the appearance of the plant will change. The morphological changes of sugarcane stem and leaves are shown in Figure 1a-b. The healthy sugarcane stems are relatively thick; the susceptible sugarcane stems are relatively small, and the internodes are long. After the main stem grows black spikes, the lateral buds also grow with the smut. Figure $1 \mathrm{~b}$ shows the changes in sugarcane leaves. Compared with the cells of healthy sugarcane buds, obvious pathological changes occurred in the mitochondria and other cell organelles in the stalk bud cells infected by smut (Figure 2). The cells of healthy sugarcane buds are relatively regular, and there are organelles such as mitochondria, golgi apparatus and endoplasmic reticulum. The nucleus has clear nucleoli and bilayer membrane structure (Figure $2 \mathrm{a}-2 \mathrm{j}$ ); the mitochondrial outer membrane structure is complete and elliptical shape, the ridge formed by intimal invagination is clearly distinguishable (Figure $2 \mathrm{~m}$ ). The cells of the diseased sugarcane buds were obviously deformed, and no intact organelles were observed.

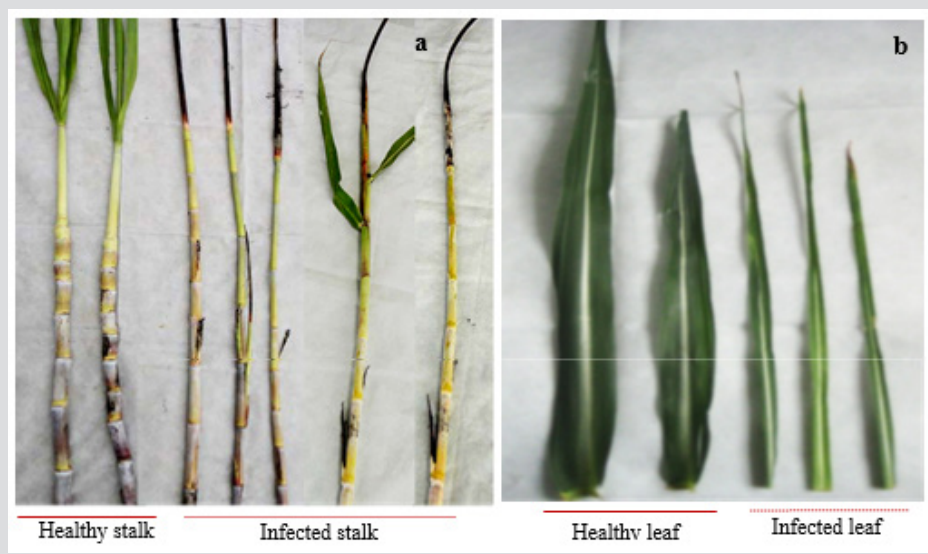

Figure 1: Effect of smut pathogen on stalk (a) and leaf (b) in sugarcane plant.

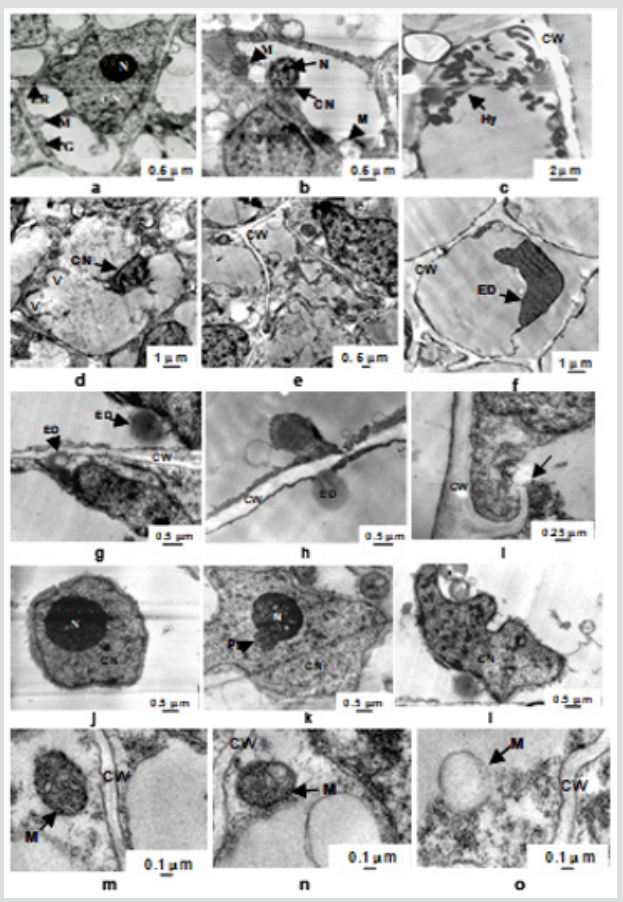

Figure 2: Changes of smut pathogen infection on ultrastructure of bud cells in sugarcane plant. a: healthy bud cell; b-f: smut infected bud cell; g-i: cell wall in smut infected bud cell; j: nucleus in healthy bud cell; k-l: nucleus in smut infected bud cell; m: mitochondria in healthy bud cell; n-o: Mitochondria in smut infected bud cell.

Note: CW- cell wall, CN- cell nuclear, N- nucleus, ER- endoplasmic reticulum, G- golgi, M- mitochondria, ED- electron dense, V- vesicle, Pa- papillary \& Hy- hypha. 
The mycelium was inside (Figure 2c), the nucleus was dissolved and dispersed (Figure 2e), and the cell wall was destroyed (Figure 2i), the cells are vacuolated, the nucleus becomes small or distorted, the nucleolus becomes smaller or disappears (Figure 2b, 2d \& 2f), and even the whole cell contains only some black electron dense material (Figure 2f); mitochondrial distortion (Figure 2b), or inner ridge blurring (Figure $2 \mathrm{n}$ ), or even vacuolization (Figure 2o); significantaccumulation of electron dense matter on or near the host cell wall (Figure $2 \mathrm{~g} \& 2 \mathrm{~h}$ ), a large number of vesicles appear in the cells (Figure 2d); compared with the nucleus of healthy sugarcane buds (Figure 2a). There is a mastoid at the edge of the nucleolus on the nucleus of Figure 2k. In Figure 2, the nucleus becomes irregular, the nucleolus has disappeared, and the chromatin distribution is uneven and degraded. There are similar findings on the external morphological changes of sugarcane caused by smut infection [2628], but most of them are only described by words, but no intuitive figures are used to describe them. This experiment compared the appearance and morphological changes of stems, leaves and whole plants of sugarcane healthy plants and susceptible plants. The interaction between rice and rice blast fungus, the rice plasma membrane, nuclear membrane, nucleoplasm, chloroplast and mitochondria were damaged to varying degrees after infestation

\section{and hormonal metabolic disorders [30].}

Table 1: The effect of peroxidase (POD), superoxide dismutase (SOD), polyphenol oxidase (PPO), chitinase and $\beta$-1,3-glucanase activity of sugarcane leaves after inoculation with Ustilago scitaminea Syd.

\begin{tabular}{|c|c|c|c|c|c|c|}
\hline Characteristics & Treatment & \multicolumn{5}{|c|}{ Days after inoculation } \\
\hline \multirow{4}{*}{ (U.g-1FW) } & & 1 & 3 & 5 & 7 & 9 \\
\hline & Control & 5.3 & 6.4 & 3.8 & 7.1 & 4.9 \\
\hline & Inoculated & 5 & 8.3 & 4.2 & 10.8 & 5.1 \\
\hline & Increase/ decrease (\%) & 5.66 & +29.69 & +10.59 & +52.11 & +4.08 \\
\hline \multirow{3}{*}{ (U.g-1FW) } & Control & 98 & 96.2 & 94.1 & 102 & 93.3 \\
\hline & Inoculated & 96.2 & 107 & 100.3 & 105.3 & 104.1 \\
\hline & Increase/ decrease (\%) & 2.04 & +11.46 & +6.38 & +2.94 & +11.83 \\
\hline \multirow{3}{*}{ (U.g-1FW) } & Control & 4.9 & 5.1 & 4.7 & 6.1 & 5.2 \\
\hline & Inoculated & 5.2 & 6.2 & 5 & 8.1 & 7.2 \\
\hline & Increase/ decrease (\%) & +6.12 & +21.57 & +6.38 & +32.79 & +38.46 \\
\hline \multirow{3}{*}{ (U.g-1FW) } & Control & 64.2 & 63.2 & 60.2 & 59 & 57.1 \\
\hline & Inoculated & 65.1 & 72.3 & 70.4 & 66.3 & 64.3 \\
\hline & Increase/ decrease (\%) & +1.56 & +14.29 & +16.67 & +11.86 & +12.28 \\
\hline \multirow{3}{*}{ (U.g-1FW) } & Control & 14.5 & 14.6 & 14.9 & 15.4 & 15.1 \\
\hline & Inoculated & 14.7 & 15.4 & 15.6 & 14.9 & 14.6 \\
\hline & Increase/ decrease (\%) & +1.38 & +5.48 & +6.71 & 3.25 & 3.31 \\
\hline
\end{tabular}

Note: $+=$ percent increase

Under normal condition, there are oxidative enzyme scavenging systems (such as SOD, POD etc.) in the plant, which make the active oxygen metabolism in a low level of dynamic balance, but the pathogen infects the host and causes the infected tissue. Among these defensive enzymes, SOD mainly plays a role in scavenging superoxide anion $\left(\mathrm{O}^{2-}\right)$, while POD mainly removes hydrogen peroxide $\left(\mathrm{H}_{2} \mathrm{O}_{2}\right)$ and hydroxyl radical $(\cdot \mathrm{OH})$ produced by SOD disproportionation, thereby avoiding it causes damage to cells [31]. The activity of POD in plants is significantly increased after smut

by rice blast fungus, and finally the mitochondrial ridge completely disintegrated. Cavitation, chloroplast matrix sheet disappear [29].

\section{Changes in Biochemical Indices of Sugarcane Infected by Smut}

The activities of POD, SOD, PPO, chininase and $\beta$-1,3-glucanase were assessed after inoculation with smut at specific time interval. After inoculation, the activities found higher such as $4.08,11.83$, 38.46 and $12.28 \%$ as compare to non-inoculated sugarcane plant except $\beta$-1,3-glucanase activity. The highest percentage (52.11\%) increased of the POD at $7^{\text {th }}$ day after inoculation, SOD (11.83\%) and PPO $(38.46 \%)$ at $9^{\text {th }}$ day after inoculation as compare to control plants. After $3^{\text {rd }}$ day of inoculation, chitinase activity found maximum $(14.29 \%)$ as compare to $1,5,7 \& 9^{\text {th }}$ day after inoculation. It can be seen that 1,3 and $5^{\text {th }}$ day after smut infection, $\beta$-1,3-glucanase increased, i.e. $1.38,5.48$ and $6.71 \%$ after $5^{\text {th }}$ day and reduced (3.25$3.31 \%) 5$ to $9^{\text {th }}$ day after inoculation as compare to control (Table 1). When a pathogen infects a plant, the plant cell produces a series of physiological and biochemical changes to protect against infection by the pathogen. These changes include allergic reactions after plant disease, thickening of enamel, changes in protective enzyme activity, induction and accumulation of disease-related proteins, Days after inoculation 
the fungal hyphae. This study found that the chitinase activity of different resistant sugarcane varieties increased after inoculation with smut and reached the highest at $3^{\text {rd }}$ day after inoculation. The resistance of $\beta$-1,3-glucanase to pathogenic fungi inhibits pathogens by destroying the fungal cell wall; on the other hand, oligo- $\beta$ 1,3-glucanase. It is released from the fungal cell wall, thereby stimulating the expression of plant defense genes to produce a disease-resistant response [33]. This experiment showed that the activity of $\beta$-1,3-glucanase in leaves of sugarcane seedlings was higher than that of the control in the early stage of infection.

\section{Acknowledgement}

This work was supported by the fund for Guangxi Innovation Teams of Modern Agriculture Technology (nycytxgxcxtd-03-01), Guangxi Science and Technology base and Talents projects (Gui Ke AD17195100), Guangxi Key Laboratory of Sugarcane Genetic Improvement Fund (16-A-04-02).

\section{References}

1. Sunder AR, Barnabas EL, Malathi P, Viswanathan R (2012) A mini review on smut disease of sugarcane caused by Sporisorium scitamineum, in botany. J Mworia (Rijeka: InTech Publisher), pp. 109-128.

2. Su Y, Wang Z, Xu L, Peng Q Liu F, et al. (2016) Early selection for smut resistance in sugarcane using pathogen proliferation and changes in physiological and biochemical indices. Front Plant Sci 7: 1133.

3. Li YR (2010) Modern agriculture science. Beijing: China Agriculture Press.

4. Zhide $X$, Gangshan L, Heqing H (2006) Investigation report on sugarcane diseases and insect pests in Hunan Province. Hunan Agric Sci (1): 26-27.

5. Bohui W (2007) Current status and research progress of sugarcane diseases in China. Chinese Sugar (3): 48-51.

6. Weihuai W, Rui L, Chunping H (2007) Preliminary investigation on sugarcane diseases in Hainan Island. J Tropical Crops 28(4): 112-116.

7. Weihuai W, Zujian X, Chunping H (2009) Biological characteristics of smut of sugarcane smut and the effect of fungicides on its germination. J Tropical Crops 30(11): 1674-1678.

8. Wenjie L, Wenfeng L, Yingkun H (2008) Research progress in the occurrence and control of sugarcane smut. Chinese Sugar (3): 64-66.

9. Alexander KC, Ramakrishnan K (1980) Infection of the bud, establishment in the host and production of whips in sugar- cane smut (Ustilago scitaminea Syd.) of sugarcane. Proc Int Soc Sugarcane Technol 17: 1452 .

10. Minhe Y (2002) Cellular biology of rice-rice (Magnaporthe grisea) interaction. Ph.D. thesis.

11. Mingshan J, Chen J, Huang G (2000) Study on the ultrastructure of stem rot disease of maize anti-cortisce. J Shenyang Agric Univ 31(5): 482-486.

12. Wenying Y, Tingguo P, Yuqin K (2005) Cellular ultrastructure of different resistant sweet potato varieties after infection with scab disease. J Fujian Agric and Forestry Univ (Natural Sci Ed.) 34(2): 248-251.

13. Yanling C, Zhang H (2003) Correlation between tomato leaf mold resistance and phenylalanine ammonia lyase. North China J Agric Sci 18(1): 79-82
14. Yanling C, Zhang H (2003) Correlation between tomato leaf mold resistance and phenylalanine ammonia lyase. North China J Agric Sci 18(1): 79-82.

15. Shaowu Q, Chun G, Chunlin L (2004) The relationship between the activity of some enzymes in Brassica napus $L$. and antimicrobial nucleus. Acta Agronomica Sinica 30(3): 270-273.

16. Qing C, Yindong Z (2004) Correlation between three oxidases and resistance to pepper mites. J Tropical Crops 25(3): 42-46.

17. Caixia L, Peng L, Yongfa S (2006) Effects of salicylic acid on plasma membrane permeability and protective enzyme activities of maize seedlings under cadmium stress. Plant Physiol Comm 45(5): 882-884.

18. Liping X, Jiannan W, Rukai C (1994) The biochemical reaction of sugarcane to smut and its relationship with disease resistance. Sugarcane 1(3): 13-16.

19. Aixin L, Hansong D, Yuancun L (1999) Antibacterial activity of chitinase $\beta$-1.3-glucanase. Microbiol Bull 26 (1): 15-17.

20. Xilong L, Dianfeng Z, Yuhu Z (2006) Research status and prospects of physiological and biochemical indexes of host plants under disease stress. Anhui Agric Sci 34(15): 3576-3578.

21. Huang J, Hong H, Shaoling S (2001) Screening of excellent strains of smut resistant sugarcane. Guangxi Sucrose (1): 6-8.

22. Chen Y, Guihua S, Chang Y (1997) Effects of salt stress on superoxide dismutase (SOD) in the organelles of soybean seedlings. Acta Agronomica Sinica 23(2): 214-219.

23. Boller T, Gehri A, Mauch F, Vogeli U (1983) Chitinase in bean leaves: Induction by ethylene, purification, properties and possible function. Planta 157: 22-31.

24. Tang ZC (1999) A Guide to Modern Plant Physiology. Beijing: Sci Press.

25. Yongting Y, Yuanyuan X, Huang L (2007) Effects of different combinations of carbon and nitrogen sources on extracellular $\beta$-1,3-glucanase production by total pathogens of wheat. J Northwest A\&F Univ.

26. Zhicai Y, Guoru X, Xueting C (2010) Isolation and identification of sugarcane smut in Hainan sugarcane area. J Tropical Crops 31(5): 828833.

27. Mengyu X, Fucong Z (2008) Ultrastructural changes of rice leaves in response to rice blast fungus. J Tropical Crops 29(1): 102-104.

28. Kim MS, Cho SM, Kang EY, Im YJ, Hwangbo H, et al. (2008) Galactinol is a signaling component of the induced systemic resistance caused by Pseudomonas chlororaphis 06 root colonization. Mol Plant-Microbe Interact 21: 1643-1653.

29. Ruifang S, Yongle D, Changrong G (2007) Research progress on the relationship between tobacco disease resistance and defense enzyme activity. Chinese Agric Sci Bull 23(5): 309-314.

30. Lifang W (2008) Physiological mechanism and ultrastructure of sunflower rust resistance. Master's thesis of Inner Mongolia Agric Univ.

31. Jianhua X, Zhenqing F (1997) Relationship between phenylalanine ammonia-lyase, polyphenol oxidase and muskmelon resistance to Fusarium wilt. J Shihezi Univ (Natural Sci Edn.) 1(1): 47-50.

32. Houjun S, Meiyan L, Zong Y (2011) Effects of black spot on several protective enzyme activities in sweet potato. Guangxi J Agric Sci 26(3): 14-16.

33. Baoju L, Fengyun L (1998) Changes of peroxidase and polyphenol oxidase in different resistant varieties of cucumber infected with black spot pathogen. Chinese Agric Sci 31(1): 86-88. 
ISSN: 2574-1241

DOI: 10.26717/BJSTR.2019.17.002950

Yang-Rui Li. Biomed J Sci \& Tech Res

(c) (i) This work is licensed under Creative

Submission Link: https://biomedres.us/submit-manuscript.php

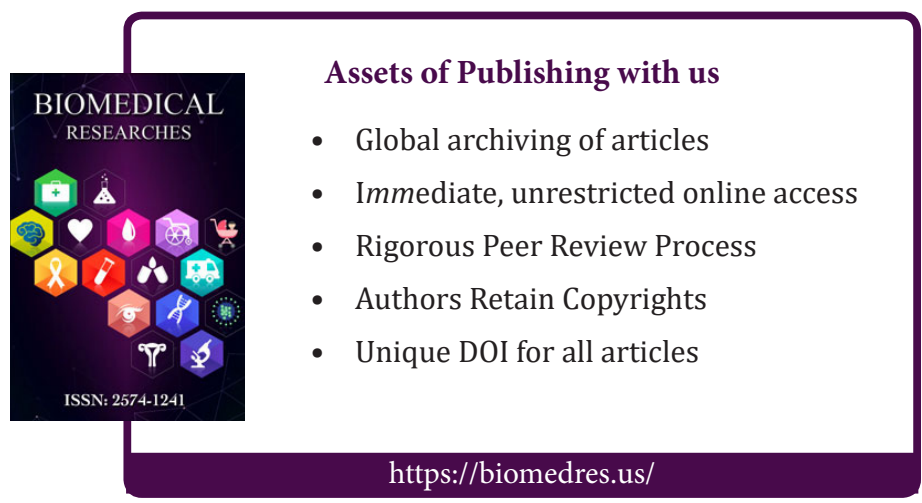

